\title{
Class oppression, commodification, and consumerism in Dreiser's Sister Carrie
}

\author{
Elham Omrani \\ University of Semnan, Iran \\ Shamsoddin Royanian \\ University of Semnan, Iran \\ Ensieh Shabanirad \\ University of Tehran, Iran
}

\section{Introduction}

Theodore (Herman Albert) Dreiser (1871 - 1945) was born to a poor Indiana farm family of ten children in 1871. Through hard work, his father became a man of wealth and position, but just before Theodore's birth a series of misfortunes rendered his family penniless. "Dreiser's childhood coincided with the family's hard times. Consequently, his earliest memories included the joblessness of his father and older siblings, as well as the constant search for economic stability" (Riggio, 2000). So, Theodore became familiar with the bitter taste of poverty from childhood. Theodore, who himself experienced the financial insecurity and the difficult condition of the poor, tried to depict the disparity between the comfortable condition of the upper class and the miserable condition of the lower class in his works. In his first novel, Sister Carrie, he portrayed class struggle, oppressive ideologies, and social inequality in a capitalist society. Therefore his work can be interpreted through Marxist literary theories. This paper reveals Marxist critique of class oppression, commodification, and consumerism in Dreiser's Sister Carrie. In this novel, the main characters are from three different classes of American socioeconomic life. The characters oppress and commodify each other to their own convenience. They exploit and victimize each other to climb the social ladder while they lead the poor ones to misery and hardship. Such kinds of commodification, class distinction, oppressive ideologies, and consumerism are the results of capitalism. So, through a Marxist reading of Sister Carrie, one can see the negative effects of capitalism on individuals and their behavior and values. In this novel, the 
oppressive ideologies of the capitalist society affect the characters badly and lead them to a brutal competition in materialism. The ruling class 'constructed' the ideologies which only serve their interests and through these false ideologies, they make the lower class believe that the upper class must be more privileged and have this right to commodify and use the lower class however they like while the lower class must be completely obedient and at the service of them. Thus, the relationship between the base and superstructure in the capitalist society is perceivable in Dreiser's Sister Carrie. The labor source, or base, is embodied by the poor workers, which is governed by the superstructure. The ruling class exploits the workers and the major benefits of their labor go directly to the pockets of the higher class. The labor of the workers is intentionally ignored by the upper class and just money talks in a capitalist society and the social values are based upon material things. Seemingly, in such a society in which everyone just cares about his or her own benefit and is willing to commodify and victimize others for what he or she desires, there is no room for morality. Dreiser's Sister Carrie is a novel so far ahead of its time and Dreiser portrayed the bitter social facts which can be found in every capitalist society, so his novel is as alive and valid today as when he wrote it. Through a Marxist reading of Sister Carrie, whatever mentioned here is going to be discussed in this paper later.

\section{A Brief Review of Dreiser's Other Novels}

Dreiser's "youth and early manhood prepared him for the themes he developed. His unstable home life; ... abject poverty; and his own desires for affluence, acceptance, sexual satisfaction, and recognition were all parts of his fictional commonplace book" (Rollyson, 2000, 311). He portrayed the unjust, unequal, and materialistic conditions of American society in his works and indeed, he was "an instrumental figure in promoting a realistic portrayal of life in America (Ryan, 1991, 872). By a brief review of some of Dreiser's more significant novels, one can perceive that Dreiser represented the negative effects of capitalism and false, constructed ideologies on people and the social competition and class struggle that come with it.

In 1900, his first novel, Sister Carrie, appeared. Sister Carrie is the story of a poor country girl who comes to city and seeks her fortune. "Influenced by... the economic determinism of Karl Marx and Friedrich Engels" (Hacht \& Hayes, 2009, 448), Dreiser severely condemned the American capitalist society for constructing false ideologies, generating class conflict, and exploiting the poor people. In 1911, Dreiser published his second novel, Jennie Gerhardt. In this novel, "Dreiser 
created a girl much like Carrie in origin, who has the same desires for material ease..." (Rollyson, 2000, 313). Jennie, the daughter of a poor washerwoman and an unemployed glassblower, worked in a hotel in Columbus, Ohio where she met Senator George Brander. He, much older than Jennie, was attracted by her youth and vitality and aimed to seduce her. Jennie, who had been financially supported by Brander, agreed to sleep with him. Shortly afterward, Brander died and Jennie was left pregnant. She gave birth to a daughter, Vesta, and went to Cleveland to work as a lady's maid. This time, she met Lester Kane, a wealthy man, who asked her to be his mistress and promised to give her financial support. In this novel, like Sister Carrie, Dreiser portrayed the flaws of his society, false ideologies, and class conflict. Dreiser's other prominent work was The Financier, published in 1912. Frank Cowperwood, a materialistic son of a banker, tried hard to make more money. Finally, he achieved his goal and became a prosperous businessman. For the sake of more money, he married an affluent widow who was older than him. But, he secretly had an affair with a beautiful, young woman, Aileen. Frank indulged in building expensive houses with luxurious furniture. He even bought fine, rare paintings and other objects of art to show off. "Cowperwood is basically a pragmatist who does what is necessary to please himself. Besides this pragmatic nature, however, Cowperwood has another side which seems anomalous in his quest for power. The other side of Cowperwood is epitomized by his simultaneous lust for and pride in his women and his art collection... Morality has no relevance in Cowperwood's understanding of the equation. He and his desires are all that exist" (Rollyson, 2000, 315). Eventually, Frank went bankrupt and was sentenced to jail. In this novel, Dreiser also censured the capitalist ideologies for intensifying people's avarice for money. Dreiser disapproved capitalist society where human relationship and value are based on money and people coldly commodify each other for the sake of financial success. In 1925, An American Tragedy was published by Dreiser. The protagonist of this novel is Clyde Griffiths, the son of poor street preachers. Clyde longed for material things which he never had in his life. He moved to New York where he met his wealthy uncle and started working in his factory. There, Clyde made the poor girl worker, Roberta Alden, pregnant and abandoned her for a beautiful, wealthy daughter of a factory owner, Sondra Finchley. Roberta threatened Clyde to reveal their secret relationship if he did not give consent to marry her instead of Sondra. Clyde did not want to lose the wealthy Sondra for the sake of the poor Roberta. "When he has his goal of wealth and success in sight, the only obstacle in his path, the pregnant Roberta, must be discarded at any cost without a thought of the consequences (Rollyson, 2000, 317). Finally, as the murderer of Roberta, Clyde was sentenced to death. This novel is another portrayal of American capitalist society condemned by Dreiser. He showed 
how people are stone-heartedly willing to sacrifice someone else for their own convenience.

Totally, Dreiser, who had experienced a difficult, poor life himself, was able to understand the abject condition of deprived people and expressed his censure against the American capitalist society and the rich, ruling class for commodifying, oppressing, and victimizing the poor, working class. E. L. Doctorow stated that Dreiser "considered the working poor to be "generally unimaginative, unaspiring, [and] terribly reduced in liveliness by the deadly and repetitive rituals of their work" (The Novelist Who Was Born Old, 1983). Dreiser shed light on the class oppression in his society and the unjust commodification of the poor, vulnerable ones and he "has been acclaimed for this sincere and profound consciousness of the tragedy of life as he saw it in America..." (Hart, 1995, 184). By reading Marx's ideas, Dreiser in his later works such as Dreiser Looks at Russia (1928, written after travels in Russia), Tragic America (1931), and America Is Worth Saving (1941), "expresses the growing faith in socialism..."(Drabble, 2000, 301). In this paper, more elaboration on Dreiser's Sister Carrie from Marxist perspective is offered.

\section{Synopsis of Sister Carrie}

The novel starts with the description of Carrie Meeber, namely, Sister Carrie. She leaves her poor country family and moves, for the hope of a better life, to Chicago to live with her sister, Minnie, and her husband, Sven Hanson. In her sister's home, she understands that she must work hard and pay the rent to the Hansons. She cannot tolerate working under the degrading and difficult condition and living with her poor sister anymore and she decides to leave them to live with her lover, Charles Drouet. Drouet supports his mistress financially and introduces her to George Hurstwood, the prosperous manager of a famous saloon in Chicago. For Carrie, Hurstwood epitomizes a higher level of success and assurance than Drouet. She abandons Drouet to live with Hurstwood in New York after Hurstwood has left his wife and children and stolen money from his employers. In New York, little by little Hurtwood's conditions get worse while Carrie achieves increasing success as an actress on the popular stages. Carrie leaves Hurtwood and devotes herself to her career completely. Hurstwood commits suicide and Carrie does not know anything about it. She aims to possess more money, beautiful clothes, and a higher position. She becomes familiar with Bob Ames, much better than Hurstwood and Drouet in Carrie's eyes. She soon loses her interest in him as well when she achieves what Bob has herself. As an ambitious woman, she still desires more and at the end of 
the novel she is not satisfied with her present life, money, and fame and seeks something better.

\section{A Literature Review of Other Reviewers' Comments on Dreiser's Sister Carrie}

Dreiser wrote Sister Carrie to reveal the bitter facts and defects of the capitalist American society. As Jim Philip stated, Dreiser's goal for writing this novel "is an attempt to convince himself and his readers of the inevitability of an intensely competitive system; this is grounded in certain basic facts of human nature, in that instinctive and universal longing for wealth, status and pleasure newly stimulated by an America in the process of compounding its own riches" (1983). Many critics approved Dreiser's honest and real depiction of American society. For instance, in 24 August 1901, the reviewer of London Academy considered Sister Carrie as "a calm, reasoned, realistic study of American life in Chicago and New York, absolutely free from the slightest trace of sentimentality or prettiness, and dominated everywhere by a serious and strenuous desire for truth" (Salzman, 1969, 130). Joseph Warren Beach also declared that Dreiser is a major American author because of "his fearlessness, his honesty, his determination to have done with conventional posturings and evasions. It was extremely important that we should have someone bold enough to set down in the English language just as he saw it the unvarnished truth about American business life, American social life in its major reaches, and the sex-psychology of American men and women" (1932). Similarly, the Toledo Blade (8 December 1900) reported that the novel "is a faithful portraiture of the conditions it represents, showing how the tangle of human life is knotted thread by thread" (Salzman, 1969, 125). Likewise, Walter Benn Michaels expressed that Sister Carrie is an "unequivocal endorsement" of "the unrestrained capitalism of the late nineteenth and early twentieth centuries" $(1987,35)$. The critic of The Interior (21 February 1901) stated that "it is undeniably true that $\mathrm{Mr}$. Dreiser has made a noteworthy addition to American literature" (Salzman, 1969, 126). Similarly, the writer for the Times Herald called Sister Carrie "a great American novel" (Salzman, 1969, 126). Regarding Dreiser's characterization, Ellen Moers, one of Dreiser's best critics, calls Ames an "intellectual Midwesterner brought on near the end of the novel to express Dreiser's own opinions," opinions which, according to Mores, centrally involve an ultimate contempt for the models of "success" represented in the novel by characters like Drouet, Hurstwood, and to some extent Carrie herself $(1969,109)$.

Although the above-mentioned critics approved Dreiser's open and honest portrayal of life's bitter realities, some critics criticized Dreiser for his overt outspokenness. For example, Dreiser's publishers withheld Sister Carrie from 
circulation, because they "were apprehensive about Dreiser's frank and amoral treatment of Carrie's sexuality and ambition"... (Drabble, 2000, 300-301). The St. Louis Mirror also complained that "the author writes with a startling directness (Kazin, 1955). Donald Pizer asserted that Dreiser's "first novel, Sister Carrie (1900), ... was chastised as well for its uncouth material and ungainly style" (1998, 179).

Definitely, there are different ideas about the same literary work. But, as these reviews demonstrate, one can perceive that Dreiser has been successful enough to attract the critics' attention to his Sister Carrie. He genuinely tried to make known the underlying, hidden facts of the American society and he is remembered as a prominent literary figure.

\section{A Brief Review of Marxist Ideas}

Before applying Marxist criticism to Dreiser's Sister Carrie, it is better to discuss some theories of Marxism. As a social psychologist, Karl Marx was concerned with the rise of a capitalist economy, because he was worried about the damaging effects and bad consequences of capitalism on human values and human psychology. Marx and his later followers focused on how ideologies are "constructed" by the ruling class and passed from one person to another and operated in people's emotional lives. "Basically Man's social being determines his consciousness and the material interests of the dominant social class determine how all classes perceive their existence" (Carter, 2006, 55).

The damaging effects of capitalism on human psychology often appear in people's relationship to the commodity. Marx, in his Capital, asserted that "A commodity is ... a mysterious thing, simply because in it the social character of men's labour appears to them as an objective character stamped upon the product of that labour; because the relation of the producers to the sum total of their own labour is presented to them as a social relation, existing not between themselves, but between the products of their labour" (Marx-Engels, 1978, 320). Trachtenberg believed that Marx's explanation of the commodity expresses the function of advertising, a kind of communication that increased in the late nineteenth century; "by animating commodities, by giving them voice and motion, advertising performed the symbolic process Marx discerned. In the world of the ad, social relations assume 'the fantastic form of relations between things"' (1982, 139). Therefore, in the societies with capitalist economic system, a commodity has impersonal value. "For Marxism, a commodity's value lies not in what it can do (use value) but in the money or other commodities for which it can be traded 
(exchange value) or in the social status it confers on its owner (sign-exchange value). An object becomes a commodity only when it has exchange value or signexchange value, and both forms of value are determined by the society in which the object is exchanged" (Tyson, 2006, 62). Thus, "commodification, then, is the act of relating to persons or things in terms of their exchange value or sign-exchange value to the exclusion of other considerations" (ibid., 69). A person commodifies an object when he or she buys it for the sake of trading, more investment, and its exchange value; as when a person purchases a costly object not just for its usefulness but for showing off and impressing others. Even a person is capable of commodifying other human beings when he/she makes his/her relationships with others in order to just make his/her own situation financially or socially better. Such a person sees other people as commodities and tries to take advantage of them and treats them like an object. Therefore, an object or even a person becomes a commodity when it has exchange value or sign-exchange value or both. Concerning the working class, Marx mentioned "surplus value" as well. "Surplus value is what accrues to the capitalist who owns the modes of production; it is the difference between wages paid and the actual work done by workers. In a capitalist society, workers are, in principle, underpaid; the value of labor expended in a day's work exceeds the wages paid for that work" (Castle, 2007, 109).

In capitalist societies, the higher, ruling classes construct false ideologies to control the lower, working classes better and in order to strengthen their economic bases, they persuade people to buy their products. One of these false ideologies is consumerism that urges people to buy more and more even if their productions are unnecessary for people's lives. "From a Marxist perspective, because the survival of capitalism, which is a market economy, depends on consumerism, it promotes sign-exchange value as our primary mode of relating to the world around us."... "In other words, in economic terms, it's in capitalism's best interests to promote whatever personal insecurities will motivate us to buy consumer goods...And because the kinds of personal insecurities that make us buy consumer products are produced by comparing ourselves with other people,...competition is promoted not just among companies who want to sell products but among people who feel they must "sell" themselves in order to be popular or successful" (Tyson, 2006, 62-3). Totally, Marxism believes that capitalism not only leads people to regard money, possession, and clothes as high achievements and ignore human's real values, but also creates class conflict in a society. As Selden, Widdowson, and Brooker declared, "the conflict of social classes establishes the ground upon which ideological conflicts arise" $(2005,83)$. Marx stated that people must be aware of different "ideological forms" and "become conscious of this conflict and fight it out" (A Contribution to the Critique of Political Economy, 1971). Generally, different authors, who were influenced by Marx, depicted the social injustice in 
their works. Theodore Dreiser is one of these authors whose works can be analyzed through Marxist perspective. As Peter Barry stated, "the exploitation of one social class by another is seen especially in modern industrial capitalism, particularly in its unrestricted nineteenth-century form" $(2002,156)$, Dreiser intended to portray the class oppression, social unfairness, and capitalist fabricated ideologies in his nineteen-century American society. This paper offers a Marxist reading of Dreiser's first novel, Sister Carrie.

\section{A Marxist Reading of Dreiser's Sister Carrie}

This paper aims to discuss Marxist critique of class oppression, commodification, and consumerism in Dreiser's Sister Carrie, tracing them mainly in the lives and characters of Carrie, Hurstwood, and Drouet around whom most of the story revolves. Besides shedding more light on these three main characters, Carrie, Hurstwood, and Drouet respectively, more elaboration is also given on the difficult condition of the poor workers.

\section{1. Discussion on Carrie's Character}

At the beginning of the novel, Carrie, who was from the middle American class, was traveling to Chicago by train. The way she is described shows her inborn tendency to pleasures and material aspect of life: “...she was interested in her charms, quick to understand the keener pleasures of life, ambitious to gain in material things" (Dreiser, 2009, 9). On the train, she met a well-dressed man, Drouet. The first thing she noticed was Drouet's clothes. "Good clothes, of course, were the first essential, the things without which he was nothing" (Dreiser, 2009, 12). It is perceivable that Carrie pays attention to the appearances a lot. At first glance, she noticed Drouet's stylish clothes; the only things which make him look valuable in her idea. So, for Carrie, the real value of people lies in what they wear. "There is an indescribably faint line in the matter of man's apparel which somehow divides for her those who are worth glancing at and those who are not. Once an individual has passed this faint line on the way downward he will get no glance from her" (Dreiser, 2009, 13). But, in case of Drouet, who dressed more fashionably and much better than Carrie, she felt ashamed of her own clothes. "Her own plain blue dress, with its black cotton tape trimmings, now seemed to her shabby. She felt the worn state of her shoes" (Dreiser, 2009, 13-14). Therefore, one can easily perceive that Carrie has the potential for commodifying others, since after noticing Drouet's sign-exchange value, she noticed his exchange value. "He reached down in his hip pocket and took out a fat purse. It was filled with slips of paper, some mileage books, a roll of greenbacks. It impressed her deeply" (Dreiser, 
2009, 16). Carrie showed a strong tendency to Drouet's wealthy, beautiful clothes and his money-filled purse. "The purse, the shiny tan shoes, the smart new suit, and the air with which he did things, built up for her a dim world of fortune, of which he was the centre. It disposed her pleasantly toward all he might do" (Dreiser, 2009, 17).Drouet seemed to Carrie the epitome of wealth and influence.

In Chicago, when the poor Carrie looked at other rich people, she wished to own what they had. "A flame of envy lighted in her heart. She realised in a dim way how much the city held - wealth, fashion, ease - every adornment for women, and she longed for dress and beauty with a whole heart" (Dreiser, 2009, 43). Carrie was innately attracted to the rich, stylish people and things and "she was struck with the evidences of wealth..." (Dreiser, 2009, 62). She liked the luxurious style of the higher class people and since she was none of them she felt ashamed and upset. One day when she was in search of work, she met Drouet in the street. They went to a beautiful restaurant together and as they were having their lunch, once again, Carrie noticed Drouet's stylish appearance. "As he cut the meat his rings almost spoke."..."He was a splendid fellow in the true popular understanding of the term, and captivated Carrie completely" (Dreiser, 2009, 110). Carrie had a high opinion of Drouet because of his wealth and nice clothes not because of his personality. "Drouet must be fortunate. He rode on trains, dressed in such nice clothes, was so strong, and ate in these fine places. He seemed quite a figure of a man..." (Dreiser, 2009, 111). To Carrie, Drouet seemed the very picture of substantial living and she noticed Drouet's sign-exchange value and was impressed. Carrie liked Drouet for what he had and she herself was deprived of, i.e. money and fashionable clothes. As soon as Drouet offered her his money, Carrie started thinking about what she could buy with Drouet's money. At heart, Carrie is happy that she can have access to Drouet's exchange value, but the problem is that she can imagine no way to explain her good fortune to her sister, Minnie, and she was forced to return the money to Drouet the next day. Thus, it was her sister who made Carrie refer to her conscience and moral values not Carrie herself who was yearning for money and stylish clothes. But finally her materialistic desires overcame her moral conscience and she willingly commodified Drouet and now that she had Drouet's money in her hand "she felt that she was immensely better off for the having of them. It was something that was power in itself" (Dreiser, 2009, 116). Through Drouet, she became something of an insider of the world of wealth, fashion, and pleasure. So, for her, Drouet is a means to climb the social ladder, she steps on him to ascend to a higher class life style with better and more comfortable condition. Carrie shows potential for growth to a higher position and a change for a better life. Carrie left her sister and attended Drouet to have financially a better life and to be supported by his money and to use his exchange value and "...she was glad she had Drouet's 
money" (Dreiser, 2009, 121). So, Carrie has this tendency and capability of seeking wealth and commodifying others to her own convenience.

Carrie's new life started with the wealthy Drouet. Although she bought beautiful, new clothes with Drouet's money, she still asked him to buy her more. In such a capitalist society, people like Carrie and Drouet are influenced by its ideologies. "Classical Marxism saw ideology as part of the superstructure, the cultural practices and ideas that were shaped by the economic base; ideology in this sense constituted the ideas of the ruling class, and was the equivalent of "false consciousness," a kind of illusion that kept people from grasping the scientific or objective truth about their real conditions of existence" (Klages, 2012, 42). One of these false consciousnesses is consumerism. Carrie, who had stylish clothes, yearns to buy more and more, as if in such a society, the value of people is determined by what they buy. The more a person buys the more powerful and valuable he or she is.

Carrie spent a great, enjoyable time in the city and enjoyed being an attractive, well-dressed woman with Drouet as her escort. Obviously, she finally achieved her goal and could commodify Drouet, because "the commodity fetish occurs when exchange value takes on a power of its own that abstracts an item's use into mere status value" (Guerin, et al. 2011, 161). Carrie was happy she could have Drouet's exchange value and sign-exchange value as well. In order to keep this good situation permanent, Carrie sought to marry Drouet. She herself knew that she had no special love for Drouet, but she thought that marriage would be insurance against losing his affection and generosity. Carrie, who "really was not enamoured of Drouet" (Dreiser, 2009, 174), was worried about losing Drouet and his interest and attention to her, because in that case she would be no longer able to have access to his money and she might lose all of these relaxed and enjoyable situations. "She would have been utterly wretched in her fear of not gaining his affection, of losing his interest, of being swept away and left without an anchorage"(Dreiser, 2009, 174). "Drouet is, for Carrie, an escape. She does not love him, but his means are a source of amazement, ... he is only an intermediary in her movement from poverty to affluence" (Rollyson, 2000, 312).

One evening the young couple, Drouet and Carrie, are visited by George Hurstwood, a friend of Drouet's, the manager of a "way up, truly swell saloon", who was mature and attractive. As soon as Carrie saw Hurstwood, she immediately started comparing him with Drouet. "When Hurstwood called, she met a man who was more clever than Drouet in a hundred ways."... "His great charm was attentiveness" (Dreiser, 2009, 174). "His clothes were particularly new and rich in appearance" (Dreiser, 2009, 176). Carrie, who paid so much attention to the appearance of people, even noticed the small details of Drouet's and 
Hurstwood's clothes. "What he wore did not strike the eye so forcibly as that which Drouet had on, but Carrie could see the elegance of the material. Hurstwood's shoes were of soft, black calf, polished only to a dull shine. Drouet wore patent leather but Carrie could not help feeling that there was a distinction in favour of the soft leather, where all else was so rich" (Dreiser, 2009, 176). Carrie had the potential for being attracted to the stylish, wealthy appearances of people and in case of Hurstwood, "Carrie was thoroughly impressed. She had never come in contact with such grace" (Dreiser, 2009, 181); she noticed Hurstwood's signexchange value. At first, she was attracted to the appearance of well-dressed Drouet, then "she was used to Drouet's appearance" (Dreiser, 2009, 176). Now that she has met a better well-dressed and wealthier man, i.e. Hurstwood, she is attracted to him. So, she easily commodified Drouet and used his money, then without thinking about morality, she is fascinated by Hurstwood. "Thus, the morally uncommitted heroine of Sister Carrie is motivated by her "guiding principle" of self-interest in her languid quest for position and possessions,..." (Hussman, Jr., 1983, 215).

After her last meeting with Hurstwood, although Carrie lived with Drouet, she thought of Hurstwood. Since for Carrie, Drouet was just "touch of patronage", she was willing to throw him away to gain a better and wealthier and more prestigious man like Hurstwood. As soon as Hurstwood appealed to her, she considered his position and wealth and did not care about the moral aspects: "Here was this greatest mystery, the man of money and affairs sitting beside her, appealing to her. Behold, he had ease and comfort, his strength was great, his position high, his clothing rich, and yet he was appealing to her. She could formulate no thought which would be just and right. She troubled herself no more upon the matter. She only basked in the warmth of his feeling, which was as a grateful blaze to one who is cold" (Dreiser, 2009, 230).

Carrie liked to forsake Drouet for Hurstwood. Carrie considered Hurstwood as an ideal figure, a man from the "higher world" of wealth, power, and influence. She was ready to join to Hurstwood's higher world. She denied Drouet's presence in her life and just mused about her lover, Hurstwood; "she gave little thought to Drouet, thinking only of the dignity and grace of her lover..." (Dreiser, 2009, 235). Carrie was overwhelmed by Hurstwood and "watched his every movement with pleasure. She almost forgot poor Drouet..." (Dreiser, 2009, 247). So, Carrie commodified Drouet and when she found a better, wealthier man, she wanted to leave Drouet. Carrie "wanted pleasure, she wanted position", and now that she was at the center of Hurstwood's attention and affection, she started feeling powerful and happy. Having Hurstwood in her life, "she was now experiencing the first shades of feeling of that subtle change which removes one out of the ranks of the 
suppliants into the lines of the dispensers of charity" (Dreiser, 2009, 350). Now that Carrie felt powerful and was under the financial and emotional support of Hurstwood, did not care about Drouet and did not need him anymore and felt independent of him: "Carrie was still with him, but not helpless and pleading. There was a lilt in her voice which was new. She did not study him with eyes expressive of dependence" (Dreiser, 2009, 351). Obviously, Carrie had commodified Drouet and now she left him to commodify another man, Hurstwood, who is more affluent, influential and powerful than Drouet. She was not reluctant to use Hurstwood's exchange value and sign- exchange value for her own benefits and convenience.

Hurstwood and Carrie traveled to New York. At first, everything went well, but gradually as Hurstwood lost his power and wealth, Carrie's interest in him reduced. Hurstwood could not support her financially like before and Carrie once again, feels herself cut off from the higher world. She was free to leave Hurstwood, but she had not found a better financial support for herself and was dependent on him, so she was forced to stay with him then. In their neighborhood, Carrie met Mrs. Vance, a young lady of fine manners and expensive taste. They became friends and Carrie noticed Mrs. Vance's appearance. Although Carrie's clothes were good enough, she compared herself with Mrs. Vance. The false ideology, i.e. consumerism aroused a sense of rivalry and competition in Carrie. "Carrie had gotten herself up charmingly enough, but this woman pained her by contrast. She seemed to have so many dainty little things which Carrie had not"... "Carrie felt that she needed more and better clothes to compare with this woman, and that anyone looking at the two would pick Mrs. Vance for her raiment alone"... "There was some difference in the clothing of the two, both of quality and age, but this difference was not especially noticeable. It served, however, to augment Carrie's dissatisfaction with her state" (Dreiser, 2009, 547).

In such a capitalist society, consumerism is instilled into people's minds and people like Mrs. Vance bought a lot of clothes just for showing off. In such a society, consumerist ideologies make people believe that the more they buy and possess the more valuable and superior they are. In such a consumerist society, seemingly the value of a human lies in his or her power of purchasing. These people buy clothes not because they need them, but because they want to show off their sign-exchange value. These people with elegant clothes have a high selfconfidence while people whose clothes look cheaper feel ashamed. In case of Carrie and Mrs. Vance, Carrie is the one who wished to look like Mrs. Vance. As they walked, "the whole street bore the flavour of riches and show, and Carrie felt that she was not of it. She could not, for the life of her, assume the attitude and smartness of Mrs. Vance, who, in her beauty, was all assurance. She could only 
imagine that it must be evident to many that she was the less handsomely dressed of the two. It cut her to the quick, and she resolved that she would not come here again until she looked better. At the same time she longed to feel the delight of parading here as an equal. Ah, then she would be happy!" (Dreiser, 2009, 549-550)

About a month later, the Vances invited Carrie to dine with them at a very expensive restaurant where Carrie met Mrs. Vance's cousin, Bob Ames. Carrie was attracted to the good appearance of Ames. Again Carrie started comparing the men in her life and then desired the best one. For Carrie, Ames "seemed wiser than Hurstwood, saner and brighter than Drouet" (Dreiser, 2009, 572-3). After that night, Carrie did not see Ames again for some time, she was so impressed by Bob that she thought "she had an ideal to contrast men by - particularly men close to her" (Dreiser, 2009, 578). In comparison to the young Ames, Hurstwood seemed old and uninteresting to her. She did not like Drouet either, who seemed "gloomy and taciturn, not a young, strong, and buoyant man" (Dreiser, 2009, 586). She kept on thinking about Bob, "he was a strong man and clean-how much stronger and better than Hurstwood and Drouet..." (Dreiser, 2009, 594). Carrie could not bear Hurstwood's poor conditions anymore and she had a bitter quarrel with him over their poor condition which caused Hurstwood to leave the apartment. After his leaving, Carrie thought that he has left her forever. This thought did not worry her, but the thought of being left without any money frightened her. So, Carrie who commodified Hurstwood was still dependent on him for financial support. She did not care about Hurstwood himself, but she was afraid of losing his exchange value. So, after their quarrel, "she thought, at first, with the faintest alarm, of being left without money - not of losing him, though he might be going away permanently" (Dreiser, 2009, 645). Carrie resolved to find a job for herself and become independent like Ames. She started working in the Casino Theater, but was unwilling to give her salary to Hurstwood and wanted to buy new clothes for herself. For example when Hurstwood asked him to move to a smaller place with him and was in need of money, "she resolved to spend her money for clothes quickly, before something terrible happened" (Dreiser, 2009, 774). Seemingly, she cared for buying new clothes more than Hurstwood. Another example is when she wrote a letter to Hurstwood and said that "I'm going away. I'm not coming back any more"... "I need what little I make to pay for my clothes" (Dreiser, 2009, 781). She was so affected by the ideology of consumerism that she wanted to spend all the money she made for clothes and costumes rather than helping Hurstwood, who needed money in such a difficult situation. Through Marxist perspective, one of the bad effects of capitalism on human values is that it reduces all human relations to commercial relations. Even the family cannot escape such commodification. Carrie commodified her husband and used his exchange value and sign-exchange value, after Hurstwood lost his power and wealth, she did not care about him and she 
thought about her own material and financial conditions. Now that Carrie financially feels independent and secure, as Amy Kaplan states, "she tries to have a place for herself that is both prestigious and pleasurable" $(1988,145)$.

Carrie started pondering about her relationship with Hurstwood and found out that Hurstwood is useless now and has become a deadweight to her, so "she thought of leaving Hurstwood and thus making him act for himself,..."(Dreiser, 2009, 771). She coldly ignored him as she had ignored Drouet before. When Drouet or Hurstwood had money and provided financial security for her, Carrie stayed with them, but as soon as she felt financially independent, she ignored them both. She used them and stepped on them to achieve a higher position and to gain what she desired, then forgot them indifferently and since she did not need them anymore, she threw them away like a useless commodity. After leaving Hurstwood, in a few years Carrie became a famous and wealthy stage comedienne as she desired once while the poor Hurstwood fell into misery and begged from other people and finally committed suicide. In such a capitalist society, people have no financial security. They commodify and victimize each other to their own convenience while they lead others to misery. In this novel, the roles of Carrie and Hurstwood changed and Carrie, who used Hurstwood as a means of achieving her desires, gained wealth and fame while Hurstwood was led into poverty and death. Carrie even did not bother herself to see what happened to the poor Hurstwood. She was so amused with the new world of wealth and fame that she did not know anything about Hurstwood's suicide. After Hurstwood's death, Drouet came back again and wanted to see Carrie, but Carrie, who was financially independent and did not need Drouet like before, was not willing to be with him once again. It is perceived that not only Carrie commodified both Drouet and Hurstwood but she was willing to do the same with Bob Ames. Since at first, she liked Ames very much, she wanted to have what he had and she was deprived of. But now that she gained whatever she desired, she is not interested in him like before. "She could hardly tell why the onetime keen interest in him was no longer with her. Unquestionably, it was because at that time he had represented something which she did not have; but this she did not understand" (Dreiser, 2009, 862).

\section{2. Discussion on Hurstwood's Character}

As discussed above, Carrie was capable of commodifying others; commodification also exists in Hurstwood's character and he was not the innocent victim of Carrie's commodification, but he himself had the capability of commodifying others, including Carrie. At first, Hurstwood was a very acceptable individual of the great American upper class. Hurstwood's sign-exchange value was noticeable and "he was the picture of fastidious comfort" (Dreiser, 2009, 86). He was well known by 
many individuals, such as Drouet who came to Hurstwood's saloon and visited him. Whenever Hurstwood was upset and his business did not go well, he accepted Drouet to accompany him and change his mood. So, Hurstwood commodified Drouet and used him just for having fun not for a real friendship. "Drouet had what was a help in his business, a moderate sense of humour, and could tell a good story when the occasion required" (Dreiser, 2009, 83). When Drouet introduced Carrie to Hurstwood, he was attracted to Carrie's beauty, youth, and vitality. Without considering morality, Hurstwood desired to have Carrie for himself and "he troubled himself not at all about Drouet's priority" (Dreiser, 2009, 191). Thus Hurstwood was willing to victimize his rival to achieve Carrie and he had the capability of destroying another person's life just to gain what he wanted. With Carrie's presence, Hurtwood felt young again and he wanted to use her youth and liveliness to refresh himself. "Such youth and prettiness reacted upon him more subtly than wine" (Dreiser, 2009, 247). He commodified Carrie and compared her to a fresh fruit which shows Carrie was like an object for him that he wanted to use: "Hurstwood felt the bloom and the youth. He picked her as he would the fresh fruit of a tree. He felt as fresh in her presence as one who is taken out of the flash of summer to the first cool breath of spring."... "He was a youth again in feelinga cavalier in action" (Dreiser, 2009, 221-2). He commodified Carrie and wanted her for his enjoyment and "had only a thought of pleasure without responsibility."... "Carrie's love represented only so much added pleasure. He would enjoy this new gift over and above his ordinary allowance of pleasure" (Dreiser, 2009, 236). After he confessed his interest in Carrie, he asked then if she is now his "own girl" which shows he wanted to possess Carrie as he possessed other things.

Hurstwood and Carrie left Chicago and started a new life in New York. Everything went well till Hurstwood's passion for Carrie cooled down. He did not pay attention to her like before and just thought about his glorious past time or how to make money at the present time. As Hurstwood continued brooding, only the newspapers and his own thoughts were important to him and "the delight of love had again slipped away" (Dreiser, 2009, 587). Gradually Hurstwood felt this change for the worse and he began to see himself outside "the walled city" of youth, easy money and fine clothes. Hurstwood got tired of searching for a job in New York and relied on Carrie for affording the expenses. Carrie found a work in the theater while Hurstwood stayed at home reading the newspaper. Hurstwood still commodified Carrie and this time he wanted to use her money. "He schemed to make what she earned cover all expenses, but seemed not to trouble over adding anything himself' (Dreiser, 2009, 701). Carrie became aware of Hurstwood's misusing and commodifying her and left him. After Carrie's leaving, his financial condition got so awful that he turned to a beggar. He could not bear such a difficult 
condition and decided to commit suicide and while sighing to himself, he said: "what's the use?" which shows he was a utilitarian man and looked for the 'use' of everything and everybody.

\section{3. Discussion on Drouet's Character}

The potential and tendency of commodifying others also exist in Drouet's character. In the beginning of the novel, the first reason that Drouet was attracted by Carrie was her beauty. So, he decided to approach Carrie and his "daring and magnetism" which was "born of past experiences and triumphs, prevailed" (Dreiser, 2009, 10). Obviously, Drouet had previous experiences for being attracted by women's beauty and persuading them to be with him and this time he wanted to triumph over Carrie. After his separation from Carrie in the train station, Drouet went to Hurstwood to tell him about Carrie. The way Drouet described Carrie for Hurstwood shows that Carrie seemed like an object for him which he liked to possess. Drouet told Hurstwood: "I struck a little peach coming in on the train Friday"... "She was a little dandy, I tell you" (Dreiser, 2009, 90). The next time that Drouet met Carrie, he gave money to her, because he liked her beauty and wanted to impress and win her to have her beauty for himself. "He would not have given the same amount to a poor young man, but we must not forget that a poor young man could not, in the nature of things, have appealed to him like a poor young girl. Femininity affected his feelings" (Dreiser, 2009, 117-8). Drouet bought nice clothes for Carrie, because he wanted to make her newly found "little peach" look more attractive and beautiful in order to enjoy her beauty more whenever he looks at her and to show off her beautiful partner to others, including Hurstwood; indeed, "having a pretty mistress, and being known to have one, flatters his vanity" (Unger, 1974, 502). Totally, Drouet was attracted by pretty women and wanted to have them with himself and of course, Carrie was not the first woman whom he treated like this. Drouet had a special regard for all women, a "regard which he had for all members of the sex" (Dreiser, 2009, 235). He was instinctively fascinated by the beauty of women, including Carrie. So, he did not want Carrie for what she really is, but it was a habit in his personality to be attracted by beautiful women and enjoy them as beautiful objects. "Now, in regard to his pursuit of women, he meant them no harm, because he did not conceive of the relation which he hoped to hold with them as being harmful. He loved to make advances to women, to have them succumb to his charms, not because he was a coldblooded, dark, scheming villain, but because his inborn desire urged him to that as a chief delight" (Dreiser, 2009, 118). Now that he could commodify and win Carrie as an object for his delight, Drouet felt happy. "He was drawn by his innate desire to act the old pursuing part. He would need to delight himself with Carrie as surely as he would need to eat his heavy breakfast" (Dreiser, 2009, 140). 
One day when Drouet and Carrie were walking in the street, although he had Carrie besides himself, he still noticed the beauty of other women. "Drouet had a habit, characteristic of his kind, of looking after stylishly dressed or pretty women on the street and remarking upon them" (Dreiser, 2009, 183). His constant remark about the appearance of other women caused Carrie to compare herself with them. "He could not see that it would be better to make her feel that she was competing with herself, not others better than herself" (Dreiser, 2009, 185). In such a society, the false ideologies like consumerism make people believe that they do not look good enough and if they want to improve appearance, they must buy the commodities and clothes which a consumerist society offers. People, like Carrie, imitate and follow these false ideologies and buy more than what they really need to look more attractive, but they do not know that they strengthen the basis of capitalism alongside its false ideology, consumerism, more by purchasing their unnecessary products.

Drouet just wanted to spend time with his beautiful object, Carrie, and did not want to marry her. But after Carrie left Drouet and became a rich, prosperous actress, he desired to regain her and even marry her. "He began to imagine it would not be so difficult to enter into her life again, high as she was. Ah, what a prize! he thought. How beautiful, how elegant, how famous! In her theatrical and Waldorf setting, Carrie was to him the all desirable" (Dreiser, 2009, 855). After Carrie rejected him "Drouet abandoned his claim and was seen no more" (Dreiser, 2009, 896). Therefore, it is obvious that he wanted to commodify Carrie and his love for her was insincere, since as soon as Carrie rejected her, he easily forgot everything and continued his previous way of life. Obviously, in such a capitalist society, everyone tries to victimize and commodify the other one for his or her own benefit. In such a cruel competition for money's sake, there is no financial security for anyone. It is possible that a person who is wealthy and powerful one day becomes poor and miserable the other day, like Hurstwood who was rich and powerful one day, but fell to poverty and beggary.

\section{4. Discussion on the Working Class's Condition}

In this society, the conditions of the poor lower class and the workers are awful and the higher class tries to oppress and exploit them by means of constructing false ideologies. According to Abrams "in any historical era, the dominant ideology embodies, and serves to legitimize and perpetuate, the interests of the dominant economic and social class" $(2005,181)$. The upper classes actually justify their unfair commodification and oppression of the lower classes by instilling their false constructed ideologies into people's mind. "It is the nature of ideology to conceal the reality of class struggle from our perception and consciousness; and insofar. As 
working-class people unconsciously absorb bourgeois values, they are unwitting carriers of "false consciousness"'" (Cain et al. 2001, 762). They make the poor workers believe to work like machines without any complaint or protest and to be absolutely obedient to their authorities' orders. Actually, it is "the nature of a capitalist economy, which treats the labor of individuals as a source of commodities, eventually leads to the treatment of human beings as abstract economic quantities, again valued not for their own individual characteristics but for their economic function." It is "most directly represented in the treatment of factory workers as mere pieces of manufacturing machinery" (Booker, 1996, 73-4). Such a commodification of the workers by the upper, ruling class causes "the workers' detachment not only from that which they produce but also from society and from each other, a process called alienation, revealing what Marxist dub fragmentation, a fractured and fragmented society" (Bressler, 2007, 178). The higher class people, who live in comfortable conditions, do not care about the workers and "not the slightest provision had been made for the comfort of the employees, the idea being that something was gained by giving them as little and making the work as hard and unremunerative as possible" (Dreiser, 2009, 73). The poor workers are paid much less than what they really deserve. Here comes to mind Marx's statement about "surplus value". In such a capitalist society, workers labour a lot, but they do not receive the money equal to their hard work from their employers. They overwork and are underpaid. The poor workers, who work hard under difficult condition, not only are not appreciated for their labor but are disrespected and ignored. Capitalism and false ideologies caused people to value a human being for his or her money; the rich people are cherished by all while no one regards any value or respect for the poor. Marx and Engels wanted to criticize such capitalist societies throughout the history and asserted: "The history of all hitherto existing society is the history of class struggles" (Communist Manifesto, $2002,219)$. In such societies, people are led to cruel competition to find a better place in their society and to climb the social ladder. Obviously, the results of such a competition are class struggle and class oppression among the members of the society.

\section{Conclusion}

Marx observes that the class which is struggling for mastery must gain political power in order to represent its interest as the general interest (The German Ideology, 1987, 52-53). So, in a capitalist society, the ruling class constructs the false ideologies, and then uses its power and influence to instill them into people's minds and to make people believe them as something 'natural' in their lives. 
Actually, "it is one of the functions of ideology to 'naturalize' social reality, to make it seem as innocent and unchangeable as Nature itself. Ideology seeks to convert culture into Nature, and the 'natural' sign is one of its weapons" (Eagleton, 2008, 117).

In Dreiser's Sister Carrie, a capitalist society is depicted in which the ruling class constructed false ideologies and promoted people to follow them. In such a capitalist society, people commodify and victimize each other to their own convenience and benefits while they lead the oppressed, exploited ones to misery and difficulty. Such a cruel behavior is caused by capitalism which undermines all human values. A person's value is determined by how much money he or she has and the more money a person has, the more powerful and respectable he or she is in the eyes of other people. So in such a society, everybody just cares about financial and material aspects of life. Thus by portraying such a society, Dreiser as a narrator indirectly criticized the capitalist, consumerist society and he invited the readers to see the negative effects of capitalism on people and their lives.

\section{References and notes:}

Abrams, M.H. (2005). A Glossary of Literary Terms. Australia: Thomson.

Barry, P. (2002). Beginning theory: An introduction to literary and cultural theory (2nd ed.).

Great Britain: Manchester University Press.

Beach, J. W. (1932). The Twentieth Century Novel: Studies in Technique. USA: AppletonCentury-Crofts.

Booker, M. K. (1996). A Practical Introduction to Literary Theory and Criticism. New York: Longman Publishers USA.

Bressler, Ch. E. (2007). Literary Criticism: An Introduction to Theory and Practice. New Jersey: Pearson Prentice Hall.

Cain, W. E., et al. (2001). The Norton Anthology of Theory and Criticism. USA: W. W.

Norton \& Company, Inc.

Carter, D. (2006). Literary Theory. Great Britain: Pocket Essentials.

Castle, G. (2007). The Blackwell Guide to Literary Theory. UK: Blackwell Publishing Ltd. Doctorow, E. L. (1983). The Novelist Who Was Born Old. The New York Times. Retrieved

March 8, 2016, from http://www.nytimes.com/1983/12/04/books/the-novelist-who-wasborn-old.html?pagewanted=all

Drabble, M. (Ed.). (2000). The Oxford Companion to English Literature (5 $\left.{ }^{\text {th }} \mathrm{ed}\right)$. New York: Oxford University Press.

Dreiser, T. (2009). Sister Carrie. New Zealand: The Floating Press.

Eagleton, T. (2008). Literary Theory: An Introduction. United States: University of

Minnesota Press.

Guerin, Wilfred L., et al. (2011). A Handbook of Critical Approaches to Literature. New 
York: Oxford University Press.

Hacht, A. M., \& Hayes, D. D. (Eds.). (2009). Gale Contextual Encyclopedia of American Literature (Vol. 1) (pp. 447-450). USA: Gale Cengage Learning.

Hart, J. D. (1995). The Oxford Companion to American Literature (6th ed.). USA: Oxford University Press.

Hussman, Jr., L. E. (1983). Dreiser and His Fiction: A Twentieth-Century Quest.

Pennsylvania: University of Pennsylvania Press.

Kaplan, A. (1988). The Social Construction of American Realism. Chicago: University of Chicago Press.

Kazin, A. (1955). An Introduction to the Stature of Theodore Dreiser: A Critical Survey of the Man and His Work (pp. 3-12). A. Kazin \& Ch. Shapiro (Eds.). US: Indiana University Press.

Klages, M. (2012). Key Terms in Literary Theory. India: Newgen Imaging Systems Pvt Ltd. Marx, K. (1971). A Contribution to the Critique of Political Economy (pp. 20-21). (N. I.

Stone, Trans.). London: Lawrence \&Wishart.

Marx, K. (1978). Capital. In R. C. Tucker (Ed.), The Marx-Engels Reader (2nd ed). New York: Norton.

Marx, K. (1987). The German Ideology. (C. Dutt, Trans.). Marx/Engels Collected Works, Vol. 5. New York: International Publishers.

Marx, K., \& Engels, F. (2002). The Communist Manifesto. (S. Moore, Trans.). London:

Penguin.

Michaels, W. B. (1987). The Gold Standard and the Logic of Naturalism: American Lit erature at the Turn of the Century. Berkeley: University of California Press.

Moers, E. (1969). Two Dreisers. New York: Viking Adult.

Philip, J. (1983). Theodore Dreiser: Outsider/Insider. In R. Gray (Ed.). American Fiction:

New Readings (pp.115-32). London: Vision Press.

Pizer, D. (1998). Documents of American Realism and Naturalism. USA: Southern Illinois University Press.

Riggio, T. P. (2000). Biography of Theodore Dreiser. Dreiser Web Source. Retrieved August

25, 2015, from https://www.library.upenn.edu/collections/rbm/dreiser/tdbio.html

Rollyson, C. (Ed.). (2000). Notable American Novelists (Vol. 1) (pp. 308-318). California: Salem Press.

Ryan, B. (Ed.). (1991). Major 20th-Century Writers: A Selection of Sketches from Contemporary Authors (Vol. 1) (pp. 871-876). USA: Gale Research Inc.

Salzman, J. (1969). The Critical Recognition of "Sister Carrie", 1900-1907._Journal of American Studies. 3(1), 123-133.

Selden, R., \& Widdowson, P., \& Brooker, P. (2005). A Reader's Guide to Contemporary Literary Theory (5th ed.). Great Britain: Pearson Education Limited.

Trachtenberg, A. (1982). The incorporation of America: Culture and society in the Gilded Age. New York: Hill and Wang.

Tyson, L. (2006). Critical Theory Today, A User-Friendly Guide. London: Routledge.

Unger, L. (Ed.). (1974). American Writers: A Collection of Literary Biographies (Vol. 1) (pp. 497-520). USA: Charles Scribner's Sons. 


\title{
Summary
}

\section{Class Oppression, Commodification, and Consumerism in Dreiser's Sister Carrie}

\author{
Elham Omrani \\ University of Semnan, Iran \\ Shamsoddin Royanian \\ University of Semnan, Iran \\ Ensieh Shabanirad \\ University of Tehran, Iran
}

Theodore Dreiser, an American novelist, had experienced financial insecurity in his family and tasted the bitterness of poverty. So, through the contrast of affluence and poverty, he depicted class distinction, oppressive ideologies, and social inequality in a capitalist and consumerist society in his literary works. It is perceivable that through a Marxist reading of his works, one can feel the way he tried to portray the urban capitalist society in America in the late nineteenth century and the negative effects of capitalism on individuals and their behavior and values. This paper intends to discuss Marxist critique of class oppression, commodification, and consumerism in Dreiser's Sister Carrie. The characters in this novel commodify and oppress one another in order to achieve their own personal goals; someone victimizes another person to his own convenience and becomes a social climber while there is no financial security for the other one who falls to misery. The difficult conditions of the workers and the lower class versus the comfortable conditions of the higher class in such a capitalist society are discussed in Dreiser's Sister Carrie. Besides, the ruling class constructed false ideologies which just benefit them and they instill these ideologies into the minds of the lower class and in this way the labor source, or base, is governed by the superstructure. So, the role of ideology in the society and the Marxist view of its function in capitalist society are also discussed in this paper.

Key words: Class oppression; commodification; consumerism; Dreiser; Marxism; Sister Carrie 